\title{
水生動物を使った川の環境学習プログラムが児童の思考過程に与える影響 \\ The influence on the thought process of children through the environment learning program on the river using benthic invertebrate
}

\author{
本庄 眞 ${ }^{*}$ 浦出 俊和* 上甫木 昭春* \\ Makoto HONJO Toshikazu URADE Akiharu KAMIHOGI
}

\begin{abstract}
An environmental learning program for fourth grader was carried out using benthic invertebrate in three spots of Asuka River. We analyzed the changes of class level and individual reaction level using 20 children's composition data. As a result, it was found that the class level has advanced reaction level from interest to understanding, from understanding to thinking as a whole. According to an analysis of the children's reaction level individually, 8 children reach thinking, 18 children reach understanding, certain effects of this learning program are seen, and understanding of "relationship of space and creatures" was shown to be possible even in the development stage of fourth grader.
\end{abstract}

Keywords: river, environment learning program, elementary school, thought process, benthic invertebrate キーワード：川，環境学習プログラム，小学校，思考過程，水生動物

\section{1.はじめに}

文部省は 1992 年に「環境教育指導資料」1）を作成し（2007 年 改定）, 小学校における環境教育を「環境や環境問題に関心・知識 をもち, 人間活動と環境とのかかわりについての総合的な理解と 認識の上にたって, 環境の保全に配慮した望ましい働きかけので きる技能や思考力, 判断力を身に付ける」ことと定めた。

環境問題は広範囲で多面的であるため, 学校における環境教育 においては, 各教科, 特別活動等との連携を図りながら, 横断的で 総合的な取り組みを行う必要がある。そのため，1992 年に直接体 験の重要性を喚起する「生活科」, 2000 年には,「教科の枠を越え た横断的・総合的な学習を行い, 問題解決力を育てる」ことを目的 とした「総合的な学習の時間」が施行され，学校現場で環境教育 を行いやすい環境が整備された。しかし，環境問題の知識や理解 の獲得をどのように思考や行動につなげるかが環境教育の課題の 一つとなっている ${ }^{2)}$ 。次期学習指導要領においては, 体験活動を 「思考力」につなぐための「問題を発見する」力や「推論」する 力などを育てる「深い学び」と）とその「評価」が要請されている。

一方, 環境庁水質保全局による『水生動物による水質調査法』4) や環境庁水環境部・国土交通省河川局による『川の生き物を調心゙ よう一水生生物による水質判定一』5) を活用して，小学校におい ても水生動物を使った環境学習が盛んに行われるようになり，柴 田 ${ }^{6)}$ による生活科の実践事例，萩原ら ${ }^{7)}$ による水生動物の簡易 网鑑の提案, 河川環境財団 ${ }^{8}$ にによる全国の小学校による実践事例 報告など，様々な視点で各地域から川の環境学習事例や研究が報 告されるようになり，川の環境教育への関心が高まった。

世代的にみたとき,様々な空間的・社会的要因を受けて ${ }^{9}$ ，大学 生や親が子どもだった頃に比べて, 現在の小学生は親水度が低い 傾向にある ${ }^{10)}$ が，水辺の遊びや活動を子供時代に経験した人は, そうでない人に比べて成長してから，環境に対しての関心や意識 を持つ人が多く ${ }^{11)}$, 児童期における川の体験活動は環境学習とし ての価值は高い。

\footnotetext{
$*$ 大阪府立大学大学院生命環境科学研究科
}

伊藤ら ${ }^{12)}$ は, 小学校における川の環境学習の課題には, 大きく 「プログラム内容に関する課題」と「学習の実施に関する課題」 があり, 前者の課題については, 「学習目標が達成されるようなプ ログラムや指導計画が必要であるが，そのノウハウが不足してい る」と指摘した。本庄ら ${ }^{13)}$ は，川の環境学習の実践成果を基に, 川の環境が異なる 3 つ小学校における児童の反応レベルを分析 し, 複数地点での学習が自ら問題を発見する力や推論する「思考 力」を育てる可能性があることを示した。しかしながら，その研 究は, 分析対象が同一の児童ではなく, 複数地点の学習をプログ ラムの中に取り入れる必要性を示しているものの, それに基づい た川の環境学習プログラムが児童の思考過程に与える定量的な影 響までは示していない。

そこで, 本研究では, 先行研究と同様に複数地点において, 同 一の览童を対象に継続的に行われた「水生動物を使った川の環境 学習」が，学級集団全体や個別の児童の思考過程にどのような影 響を与えたかを定量的に分析することを研究目的とする。

\section{2. 研究方法}

\section{(1) 研究対象の選定}

本研究では，同一河川で地点を変えて継続的に行われた「水生 動物を使った川の環境学習」を対象にした。同一水系で川の構造・ 水質が異なる (表一1) 大和川水系飛鳥川の 3 か所 (祝戸, 豊浦, 田原本）（図一 1 , 写真一 1 ）において, 流域の近隣の一小学校 4 年生児童 20 名に, 2014 年 4 月から 7 月にかけて筆頭筆者が行っ た「水生動物を使った川の環境学習」を対象にした。この学習は,

「総合的な学習の時間」を使って行った。なお，同じ学級の児童 に異なる学習プログラムを実施することは教育上の観点から適切 ではないため, 対象児童には同じ学習プログラムを実施した。

\section{(2) 学習プログラムの概要}

本研究で取り上げた「水生動物を使った環境学習」の学習プロ グラム (全 16 時間) の学習目標・場所やテーマ・実施日・時間数・ 


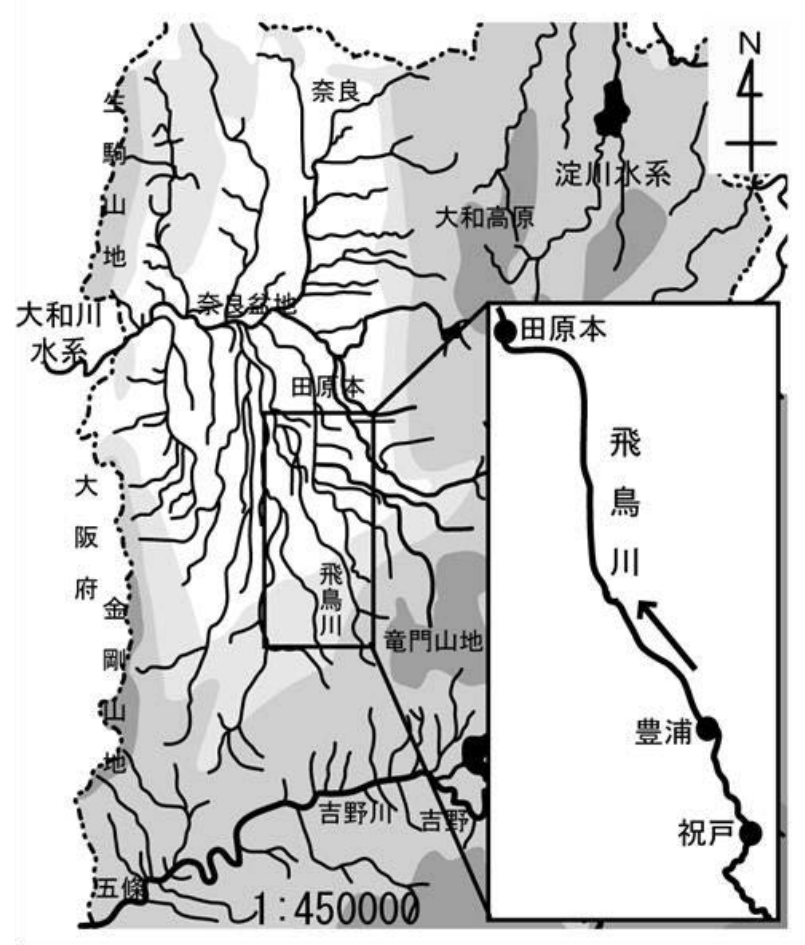

図-1 学習場所

具体的指導内容と活動内容を時系列で整理した（表一2）。

以後, 祝戸における事前学習を「第 1 次」, 祝戸における生物調 查を「第 2 次」, 豊浦における生物調査を「第 3 次」, 田原本にお ける生物調査を「第 4 次」と表した。

1) 第 1 次 (3 時間)

「きれい」な水域 (表一1) の場所である祝戸 (図-1) で,「1 淵と瀬の違いを確認し, 水温や川幅を調査し, 川で感じたことや 疑問を整理する。」を目標に実施した。

2)第 2 次

第 2 次 (5 時間)

「きれい」な水域 (表-1) の場所である祝戸 (図-1) で,「1 指標生物を使った水質調査法を知る。(2)「指標生物を使って飛鳥 川上流（祝戸）の水質が分かる。（3瀬と㴊に生息する生物に違い があることに気づく。」を目標に実施した。

$3)$ 第 3 次 (4 時間)

「きれい」な水域（表-1）の場所である豊浦（図-1）で，「1 指標生物を使って飛鳥川上流（豊浦）の水質が分かる。(2)祝戸と の生物の違いに気づく。」を目標に実施した。

4) 第 4 次 (4 時間)

「よごれた」水域（表－1）の場所である田原本（図-1）で, 「1指標生物を使って飛鳥川下流（田原本）の水質が分かる。(2) 祝戸や豊浦との生物や水質の違いに気づく。」を目標に実施した。

\section{（3）児童の反応レベルの分析}

本研究で用いた資料は，いずれも川の体験学習の 1 時間後，15 分以内に, A4 の用紙に書かれた学級全員 (20名)の作文を 1 文ず つに区切った文章で，書かれた监童の文章を対象別に，「空間」 「生物」「空間と生物」「周辺の暮らし」「その他」の 4 つのカテゴ リーに分けた。本研究の学習においては, 川幅, 水温や気温, 地 質 (砂，土，岩)，川底の状態，瀬と淵，合流に言及されている文 は【空間】のカテゴリーとした。植物，動物の採集や発見，生物 の量や形態や行動，生物の多様性，生物の飼育に言及されている 文は【生物】のカテゴリーとした。生息場所と生物の関係，生息 地点と生物の関係，水質と指標生物に言及された文は【生物と空

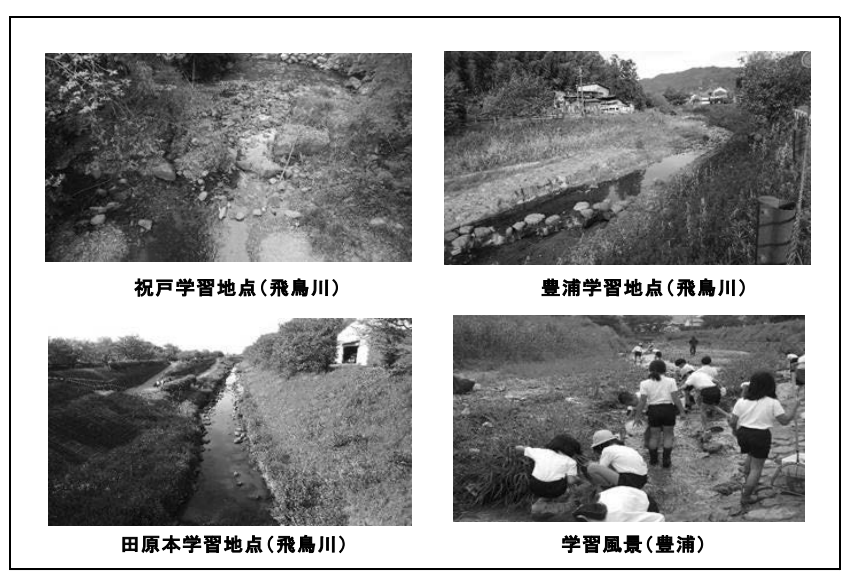

写真-1 学習場所と学習風景

表一1 学習を行った川の構造・水質

\begin{tabular}{|c|c|c|c|c|c|}
\hline & $\begin{array}{c}\text { 川幅 } \\
\text { (流水幅) }\end{array}$ & 水深 & 護岸 & 川底 & $\begin{array}{c}\text { 生物学的 } \\
\text { 水質判定 }{ }^{3)}\end{array}$ \\
\hline 祝戸 & $\begin{array}{c}17 \mathrm{~m} \\
(2 \sim 5 \mathrm{~m})\end{array}$ & $10 \sim 25 \mathrm{~cm}$ & 自然護岸 & 硬い & きれい \\
\hline 豊浦 & $\begin{array}{c}20 \mathrm{~m} \\
(3 \sim 6 \mathrm{~m})\end{array}$ & $10 \sim 25 \mathrm{~cm}$ & $\begin{array}{c}\text { 両岸コンク } \\
\text { リート護岸 }\end{array}$ & 硬い & きれい \\
\hline 田原本 & $\begin{array}{c}25 \mathrm{~m} \\
(6 \sim 8 \mathrm{~m})\end{array}$ & $10 \sim 30 \mathrm{~cm}$ & $\begin{array}{c}\text { 両岸コンク } \\
\text { リート護岸 }\end{array}$ & 軟らかい & $\begin{array}{c}\text { 少し污 } \\
\text { れた水 }\end{array}$ \\
\hline
\end{tabular}

間】のカテゴリーとした。ゴミと人間生活, 暮らしと水, 川の浄 化に言及された文は【暮らし】のカテゴリーとした。【空間】【生 物】、【生物と空間】、【暮らし】以外について言及された文を【そ の他】のカテゴリーとした。なお，ここにおける「指標生物」 ${ }^{4)}$ は水生動物のみを示した。

さらに，文科省指導要領の評価の観点 ${ }^{14)}$ を基に，巟童の作文に 見られる反応レベルを【関心】【理解】【思考】に分類した。関心】 【理解】思考】の順に環境学習レベルが高まると考えた。各分類 は以下のように定義した。関心を向けたことへの気づき,および関 心を持った事柄に対する感想や意欲を書いた文は【関心】に分類 した。関心を持ったことを元に物事を理解する過程, 知識や技術, 指導内容の確認を書いた文は【理解】に分類した。理解したこと を関係づけたり推測したりする過程，理解したことを基に得た疑 問，思考したことを基に自分として何ができるか書いた文は【思 考】に分類した。

分類の基淮を明らかにするため,【空間と生物】を例として, 具 体的な記述の分類を表一 3 に示した。例えば，「石をわたると意外 にうれしかった」などの「遊び，「魚をつかまえるのは意外にむ ずかしかった」などの「生物採集」「「メンボが特に多かった」 などの「動物の特徵」を記述した児童は川への【関心】を持った と考えた。「ヒルがいた」と指標生物を記述した児童がいても, 環 境との関係が記述されていなければ【関心】の反応レベルとし, 「ヒルが多いので，田原本は水がよごれてきている」と環境との 関係が記述できていれば，【理解】の反応レベルとした。「川底が やわらかくてサワガニがいなかった」のように生物の生息場所を 記述できていたら【理解】の反応レベルとした。「飛鳥川の, 明日 香村を出ると少し水がよごれる」と「水質判定の比較」をしてい る览童,「川底がやわらかいのにサホコカゲロウはなぜ住めるの だろう」という「空間と生物」に関する新たな課題を見つけた児 童,「ヒルやサカマキガイを少なくできるようにしようと思いま した」など「自分ごと」として行動意欲を示している児童，「おば 
表-2 学習プログラムの概要

\begin{tabular}{|c|c|c|c|c|c|}
\hline & 学習目標 & $\begin{array}{c}\text { 場所とテーマ } \\
\text { (川にスるらない) }\end{array}$ & 月 $/$ 日 & 時間数 & 具体的指導内容 - 活動内容 \\
\hline \multirow{5}{*}{ 第 1 次 } & \multirow{5}{*}{$\begin{array}{l}\text { ・淵と瀬の違いを確認し、水温や } \\
\text { 川幅などの調查し感じた } \\
\text { ことや疑問を整理する。 }\end{array}$} & \multirow{5}{*}{$\begin{array}{c}\text { 祝戸の事前学習 } \\
\text { (川に入らす) }\end{array}$} & \multirow{5}{*}{$4 / 22$} & \multirow{5}{*}{3} & ア川で気づいたことや感想・疑問を書いてもらうことを予告する。（前日） \\
\hline & & & & & (1)調査場所の水深・川幅、気温や水温をはかる。 \\
\hline & & & & & (可瀬と淵について具体的に現場で解説する。 \\
\hline & & & & & 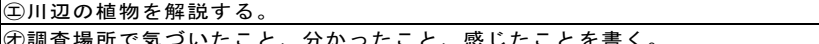 \\
\hline & & & & & 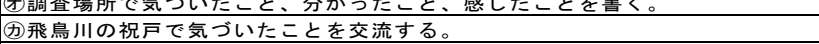 \\
\hline \multirow{10}{*}{ 第 2 次 } & \multirow{10}{*}{ 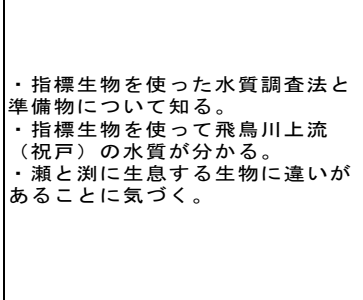 } & \multirow{10}{*}{$\begin{array}{l}\text { 祝戸の生物調査 } \\
\text { (川に入る) }\end{array}$} & \multirow{10}{*}{$5 / 7$} & \multirow{10}{*}{5} & 丹指標生物を使った水質調査法と調査の目的を説明する。（前日） \\
\hline & & & & & (つ)準備物について説明する。（前日） \\
\hline & & & & & (气)瀬と淵の違いによる生物の違いをよく見ておくように伝える。 \\
\hline & & & & & 田採集の仕方についてを具体的に説明する。 \\
\hline & & & & & 調査学習を行う。 \\
\hline & & & & & 凤児童に聞かれた生物名を教える。 \\
\hline & & & & & 也瀬と淵に生息していた生物を確認する。 \\
\hline & & & & & (D)調查終了後、調査結果を調查票で確認する。 \\
\hline & & & & & 祝戸を調査して気づいたこと、分かったこと、感じたことを書く。 \\
\hline & & & & & Ð第2次の調査で気づいたことを交流する。 \\
\hline \multirow{10}{*}{ 第 3 次 } & \multirow{10}{*}{$\begin{array}{l}\text { ·指標生物を使って飛鳥川上流 } \\
\text { (豊浦) の水質が分かる。 } \\
\text { ·祝戸との生物の違いに気づく。 }\end{array}$} & \multirow{10}{*}{$\begin{array}{c}\text { 豊浦の生物調査 } \\
(\text { 川にる }\end{array}$} & \multirow{10}{*}{$5 / 22$} & \multirow{10}{*}{4} & (2)地図上で1回目（祝戸）と2回目（豊浦）の調查場所を確認する。（前日） \\
\hline & & & & & 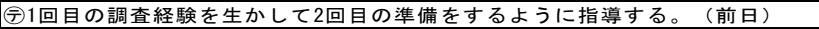 \\
\hline & & & & & 丹祝戸の生物とどのように違うかをよく観察するように指導する。 \\
\hline & & & & & $\Theta$ 調查学習を行う。 \\
\hline & & & & & 叉児童に聞かれた生物について説明する。 \\
\hline & & & & & 凤田んぼの水が入ったので、水量が増えたことを解説する \\
\hline & & & & & Ø調査終了後、調査結果を調査票で確認する。 \\
\hline & & & & & 川底の状態が水生動物におよぼす影響について説明する。 \\
\hline & & & & & (飞豊浦を調査して気づいたこと、分かったこと、感じたことを書く。 \\
\hline & & & & & $\begin{array}{l}\text { (つ)第3次の調査で気づいたことを交流し、可能であれば、家族の協力を得て他地 } \\
\text { 域での調査実施をめる。 }\end{array}$ \\
\hline \multirow{7}{*}{ 第 4 次 } & \multirow{7}{*}{$\begin{array}{l}\text { - 指標生物を使って飛鳥川下流 } \\
\text { (田原本)の水質が分かる。 } \\
\text {-祝戸や豊浦との生物の違いに気 } \\
\text { づく。 }\end{array}$} & \multirow{7}{*}{$\begin{array}{c}\text { 田原本の生物調査 } \\
(川 に 入 る)\end{array}$} & \multirow{7}{*}{$7 / 1$} & \multirow{7}{*}{4} & @地図上で 3 回目の調查場所（田原本）を確認する。（前日） \\
\hline & & & & & $\begin{array}{l}\text { 困安全面についての指導する（活動範囲や危険個所の説明）。 } \\
\text { 凤祝戸豊浦の生物と、どのような違いがあるがく観察するように指導す } \\
\text { る。 }\end{array}$ \\
\hline & & & & & （調査学習を行う。 \\
\hline & & & & & 凹児童から聞かれた生物を解説する。 \\
\hline & & & & & 凤田原本の調査結果をまとめる。 \\
\hline & & & & & 丙これまでの調査結果を「自分との関わり」で考えるように指導する。 \\
\hline & & & & & Ф田原本を調査して気づいたこと、分かったこと、感じたことを書く。 \\
\hline
\end{tabular}

表－3＼cjkstart児童の反応レベルの具体例 遮て、

\begin{tabular}{|c|c|}
\hline \multirow{19}{*}{ 関心 } & 遊ひ、 \\
\hline & 石をわたると意外とうれしかった。 \\
\hline & घ゙ミ \\
\hline & ガラスやカンが落ちていたので、はだしでつ \\
\hline & 指標生物 \\
\hline & サホコカゲロウが多かった。 \\
\hline & コイやヒル、プラナリアがいました。 \\
\hline & 指標生物上外 \\
\hline & ニゴイという大きな魚が泳いでいた。 \\
\hline & 小さな魚がいっばいいて、アメンボもいっばいいた。 \\
\hline & アメンボがたくさんいた。 \\
\hline & 生物の多 \\
\hline & 4種類しかつかまえられなかった。 \\
\hline & 動物 $\boldsymbol{~}$ 特徽（形昼 \\
\hline & 小さい魚が大群で泳いでいました。 \\
\hline & アメンボが特に多かった。 \\
\hline & 生物採复 \\
\hline & 魚をつかまえるのは難しかった。 \\
\hline & 虫をつかまえようとしたが、魚のほうに夢中になった。 \\
\hline \multirow{10}{*}{ 理解 } & 指標生物による水質判定 \\
\hline & 田原本の水はきたない。 \\
\hline & 表にの印をつけていくと、田原本の川は污いと分かった。 \\
\hline & $\begin{array}{l}\text { サホコカゲロウが特に多く、田原本の飛鳥川はきたない水と分 } \\
\text { かった。。 }\end{array}$ \\
\hline & 田原本では、サホコカゲロウや二ヨ゙イがたくさんいたが、この二つ \\
\hline & 突量間と生物 \\
\hline & 田原本の生き物は、浅瀬に集団でいる。 \\
\hline & 川の真ん中は、川底がやわらかくて、あまり生き物がいなかった。 \\
\hline & $\begin{array}{l}\text { 川底がやわらかくて、カワニナがいませんでした。もちろん、サワ } \\
\text { ガももませんでた。 }\end{array}$ \\
\hline & 石と石の間にずっと見ていると、魚が何匹がいた。 \\
\hline \multirow{9}{*}{ 思考 } & 水篮判定の比較 \\
\hline & 飛鳥川は、明日香村を出ると、少し污くなると分かりました。 \\
\hline & 然間と生物 \\
\hline & $\begin{array}{l}\text { 川底がやわらかいとカゲロウは住みにくくいとしたら、サホコカゲロ } \\
\text { ウはなぜ住めるのだうう。 }\end{array}$ \\
\hline & 思請から自分化 \\
\hline & ヒルやサカマキガイを少なくできるようにしようと思いました。 \\
\hline & $\begin{array}{l}\text { 川を污すようなことをしないようにみんなでしていくと、もっと飛鳥 } \\
\text { 川がきれいはない生き物が住みやすくなる思います。 }\end{array}$ \\
\hline & $\begin{array}{l}\text { 他地域 } へ \text { の活動転云化 } \\
\text { おばあちゃんの家の前でとれた生き物は、今日、田原でとれた }\end{array}$ \\
\hline & $\begin{array}{l}\text { おばあちゃんの家の前でとれた生き物は、 } \\
\text { 生き物とやっばり違いました。 }\end{array}$ \\
\hline
\end{tabular}

あちゃんの家の前でとれた生き物は，田原本でとれた生き物とち がいました」など「他地域への活動の転化」は，【思考】の反応レ ベルとした。なお，本研究においては，「空間と生物」は事象のつ ながりに目を向けた記述であるので，すべて【理解】または【思 考】に類別した。

1 文の中に，2 つ以上の対象の内容があったときは，より反応 レベルが高い対象に入れた。これら「対象」と「反応レベル」（【関 心】【理解】【思考】) をクロスさせて, 第 1 次〜第 4 次における児 童の反応レベルを分析した。また，ここでは，指導内容と「児童 の対象・反応レベル」の関係を明らかにするため，対象と反忘レ ベルごとに，記述のあった児童数を「反応数」として記述した。

なお, 分析にあたっては, 既往研究 ${ }^{13)}{ }^{15)}$ を参考に, 児童の具体的 反応の基準を明確にするとともに, 授業実践に関与していない共 著者 2 人が参加することにより, 客観性を確保した。

\section{（4）児童の思考過程の分析}

1）集団全体における思考過程の分析

学級全体が，どのような反応レベルの学習を獲得したかを考察 するため, 第 1 次から第 4 次までの学習過程ごとに反応数を集計 した。

\section{2）個人別の思考過程の分析}

第 1 次は，水生動物を使わずに，川を外から観察する学習で, 第 2 次から第 4 次までは,「水生動物を使った川の環境学習」だっ た。第 2 次から第 4 次までの学習過程において，個々の児童はど のような反応レベルの学習を獲得したかを考察するため, 各児童 の反応数を学習過程別に整理し, 第 2 次と「第 2 次十第 3 次十第 4 次の合計」を比較し, 各児童が 3 回の学習によってどのような 反応レベルの学習を獲得したかを明らかにする。

\section{3. 結果および考察}


表—4 学級全体における第 1 次〜第 4 次の思考過程

\begin{tabular}{|c|c|c|c|c|c|c|c|}
\hline & 反姇象 & 空間 & 生物 & 生物と空間 & 暮らし & その他 & 代表的な感想例 \\
\hline \multirow[t]{3}{*}{$\begin{array}{l}\text { 第 } \\
1 \\
\text { 次 }\end{array}$} & 関心 & 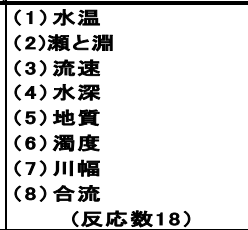 & $\begin{array}{l}\text { (9) 生物の存在 } \\
(10) \text { 植物 }\end{array}$ & & (11)ゴミ & (12) 学習活動 & \multirow{12}{*}{ 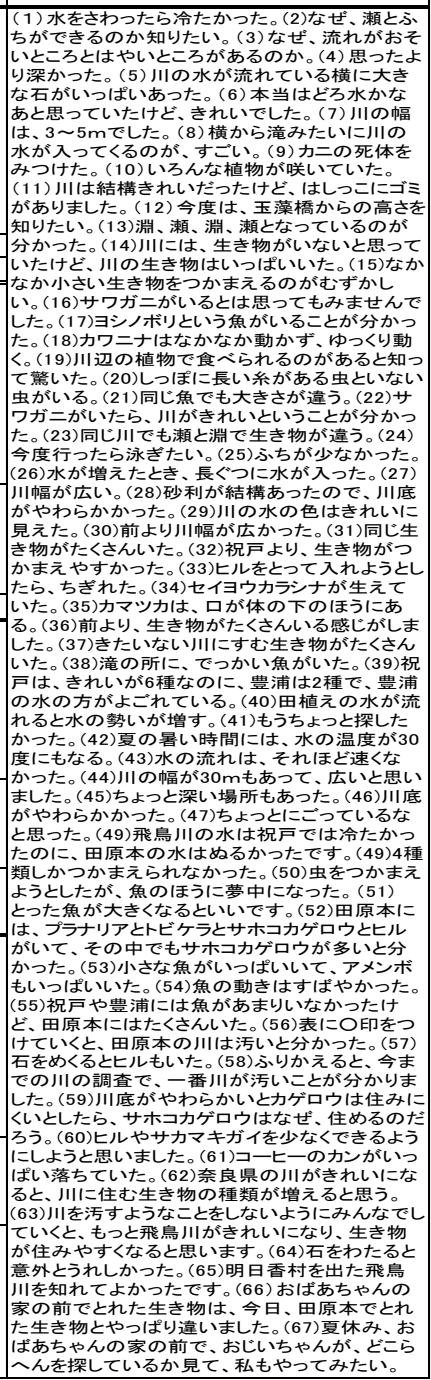 } \\
\hline & 理解 & & & & & & \\
\hline & 思考 & & & & & & \\
\hline \multirow[t]{3}{*}{$\begin{array}{l}\text { 第 } \\
2 \\
\text { 次 }\end{array}$} & 関心 & (13) 瀬と淵 & $\begin{array}{l}\text { (14)生物の存在 } \\
(15) \text { 生物採集 } \\
(16) \text { 指標生物 } \\
(17) \text { 指標生物以外の } \\
\text { 生物 } \\
\text { (18)動物の特徵 (形態 } \\
\text {-行動-食性) } \\
(19) \text { 植物 } \\
\text { (反応数 } 19)\end{array}$ & & & (24)遊び & \\
\hline & 理解 & & $\begin{array}{l}\text { (20)生物同士の比較 } \\
\text { (21)動物の成長 }\end{array}$ & $\begin{array}{c}\text { (22)指標生物による } \\
\text { 水䓄判定 } \\
\text { (23)場所と生物 } \\
\text { (反応数 14) }\end{array}$ & & & \\
\hline & 思考 & & & & & & \\
\hline \multirow{3}{*}{$\begin{array}{l}\text { 第 } \\
3 \\
\text { 次 }\end{array}$} & 関心 & 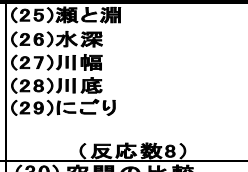 & $\begin{array}{l}\text { (31)生物の存在 } \\
\text { (32)生物採集 } \\
(33) \text { 指標生物 } \\
\text { (34)植物 } \\
\text { (35)動物の特徵 (形態 } \\
\text {-行動-量) } \\
\text { (応数 } 15)\end{array}$ & & (40)暮らしと水 & (41)学習活動 & \\
\hline & 理解 & (30)空間の比較 & $\begin{array}{c}\text { (36)地点による生物の } \\
\text { 違い } \\
\text { (反応数 7) }\end{array}$ & \begin{tabular}{|c} 
(37)指標生物による \\
水質判定 \\
(38)場所と生物 \\
(反応数8)
\end{tabular} & & & \\
\hline & 思考 & & & $\begin{array}{c}\text { (39)水質 判定の比 } \\
\text { 較 } \\
\text { (反応数2) }\end{array}$ & & & \\
\hline \multirow{3}{*}{$\begin{array}{l}\text { 第 } \\
4 \\
\text { 次 }\end{array}$} & 関心 & 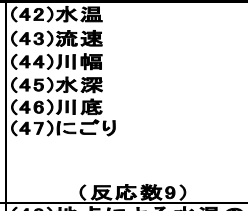 & 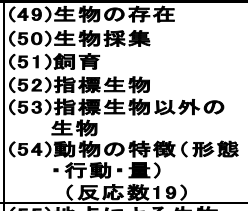 & & （反応数 8) & $\begin{array}{l}\text { (64)遊び } \\
\text { (65)学習活動 }\end{array}$ & \\
\hline & 理解 & $\begin{array}{c}\begin{array}{c}\text { (48)地点による水温の } \\
\text { (反応数 } 1 \text { ) }\end{array} \\
\text { ( }\end{array}$ & $\begin{array}{c}\begin{array}{c}\text { (55)地点による生物 } \\
\text { の運い } \\
\text { (反応数5) }\end{array} \\
\end{array}$ & \begin{tabular}{|l} 
(56)指標生物による \\
水留判定 \\
(57)場所と生物 \\
(反応数11)
\end{tabular} & (62)川の浄化と生物 & & \\
\hline & 思考 & & & 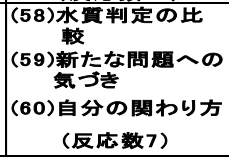 & (63)自分の関わり方 & $\begin{array}{l}\text { (66)他地域での活 } \\
\text { 動転 } \\
\text { (67)他地域での活 } \\
\text { 動計画 }\end{array}$ & \\
\hline
\end{tabular}

\section{（1）学級全体の思考過程の推移}

第 1 次から第 4 次の環境学習における対象別の反応レベルの結果 を表一 4 に整理した。

第 1 次，第 2 次，第 3 次，第 4 次における学級全体の「対象の 推移過程」を図一 2 に, 学級全体の「反応レベルの推移過程」を 図一 3 に示した。児童の学習「対象」や「反応レベル」がどのよ うに推移したか，指導内容（表一2）上「対象別の反応レベルの 結果」(表 -4 , 図一2, 図一3）を関係づけながら考察する。なお, 表一4における（）は, 反応数を示す。

\section{1)「対象」の推移過程}

学習過程に伴う学級全体の「対象」の推移過程 (図一2) を「具 体的指導内容亡活動内容」（表一 2$)$ と第 1 次から第 4 次の思考分 析（表一4）を基に考察する。

\section{( i ) 空間}

反応数は, 第 1 次 (18), 第 2 次 (3), 第 3 次 (9), 第4次 (10) だった。第 1 次（18）は，川に入らずに空間に対する調査を指示 したため，ほとんどの児童が空間に対する反忘を示した。第 2 次 （3）では，実際に川に入る水生動物による調査だったため，第 1 次に比べて減少したと考えられる。第3 次 (9) や第4次 (10) て 反応が増えたのは，学習地点が変わったため，览童は「空間の違 いや比較」に気づき，空間に対する反応を示したと考えられる。 （ii）生物

反応数は, 第 1 次 (8), 第 2 次 (21), 第 3 次 (22), 第4 次 (24) だった。第 1 次 (8) は, 川には入らずに, 空間に対する調査（ (1)(エ) だったため，空間に比べて生物に対する反応は少なかっ たと考えられる。第2次 (21)，第3 次 (22)，第4次 (24) の学 習では，実際に川に入る水生動物による調査（Ⓔ司）を行った ので，生物に対する反応が増えたと考えられる。

(iii）生物と空間

反応数は, 第 1 次 (0), 第 2 次 (14), 第 3 次 (10), 第4 次 (18) だった。第 2 次, 第 3 次, 第 4 次では,「場所と生物」の関係 (ㄱ) や「指標生物による水質判定」(本) を意識しながら生物調査をし たので，「生物と空間」に対する反応が増えたと考えられる。

(iv) 暮らし

反応数は, 第 1 次 (5), 第 2 次 (0), 第 3 次 (3), 第4次 (10) だった。第 4 次で反応数が増えたのは，祝戸や豊浦に比べて，田 原本におけるゴミの数の多さに起因していると推察される。

（v）その他

その他の反応数は, 第 1 次 (3), 第 2 次 (1), 第 3 次 (1), 第 4 次 (6) だった。第 1 次から第 3 次までは, 「学習活動」や「遊 び」についての記述であるが，第 4 次で，「他地域での活動転化 や「他地域での活動計画」が見られたのは，他地域での調査を勧 
めた（つ）ことが要因の一つと考えられる。

2）「反応レベル」の推移過程

学習過程に伴う学級全体の「反応レベル」の推移過程（図一-3) を具体的指導内容 (表一2) と第 1 次から第 4 次の思考過程の分 析（表一-3）を基に考察する。

(i ）第 1 次の反応レベル

反応数は,【関心】(34)，【理解】（0）や【思考】（0）だつた。

(ii）第 2 次の反応レベル

反応数は,【関心】(23), 【理解】（16）,【思考】（0）だった。

「指標生物を使った水質調査法」(寻) や「瀬と淵による生物の 違いをよく見ておくように」（き）という指導を基に調査 ()や 観察，結果の確認 (也) を行ったので，「場所と生物」や「指標 生物による水質判定」など「生物と空間」の【理解】（14）が生ま れたと考えられる。

（iii）第 3 次の反応レベル

反応数は,【関心】(27), 【理解】（16）,【思考】（2）だった。

空間や生物の【関心】に加えて，「田んぼの水が入ってきて水量 が増えた」という説明 (国) によって，「暮らし」への【関心】(3) が生まれたと考えられる。

第 2 次における「瀬と淵による生物の違いをよく見ておくよう に」という指示（き）や「指標生物を使った水質調査法」（用） の指導, 調査後の交流 $(\bigoplus)$, 実際の調査 $(\Theta)$ や結果の確認 $(\oslash)$ によって「生物と空間」に対する【理解】（8）が生まれたと考え られる。また，「豊浦と祝戸の違いをよく観察するように」という 指示 $(\bigoplus)$ や結果の確認 $(\oslash)$ によって, 第2 次と第3 次の比較 がなされ，「空間の比較」や「地点による生物の違い」を【理解】 （8）し，水質調査結果の違いを基に，祝戸と豊浦の水質を比較す る【思考】(2) が生まれたと考えられる。

(iv) 第 4 次の反応レベル

反応数は,【関心】(40),【理解】（18），【思考】（10）だった。

第 2 次における「瀬と淵による生物の違いをよく見ておくよう に」という指示（き）や「指標生物を使った水質調査法」（（本） の指導, 調査後の 2 回の交流 (丹ア), 実際の調査 () や結果の 確認 $(\bigotimes)$ によって「生物と空間」に対する【理解】（11）が生ま れたと考えられる。

また，「豊浦・祝戸と田原本の違いをよく観察するように」(囚) という指導によって, 第 2 次, 第 3 次の調査と第 4 次の「比較」 がなされ，「地点による水温の違い」の【理解】（1）や「地点によ る生物の違い」の【理解】（5）が生まれたと考えられる。また, 水質調査結果の違いを基に，「自分との関わり」で考える指導(㞪) を行ったので, 祝戸・豊浦と田原本の「水質判定の比較」「新たな 問題への気づき」「自分との関わり方」などの「生物と空間」や「暮 らし」の【思考】（7）, が生まれたと考えられる。また，「他地域 での調査を勧めた」(Ø)ことによって，「他地域への活動転化」 や「他地域への活動計画」の【思考】（2）が生まれたと考えられ る。

v）学級全体の「反応レベル」の推移過程

反応レベルの推移過程（図－3）より，学級全体の学習過程を 分析寸ると,【関心】から【理解】、【理解】から【思考】に反応レ ベルが進んでいると推察された。

第 2 次 (0) 加第 3 次 (2) より, 第3 次 (2) から第4 次 (10) の方が【思考】が増える傾向が見られた。その理由として，以下 の 3 点が要因として考えられる。(1)「自分との関わり」について 考えさせる指導（国）を行った。(2)第 2 次から第 3 次よりも，第 3 次から第 4 次の方が水質や環境の変化が大きい (表一 1 )。(3)継 続した学習に伴って川の生物と空間に関する理解が深まり，学習 に対する記述に慣れてきた。

「水生動物を使った川の環境学習」において，本庄ら ${ }^{13)}$ は「複
数地点での学習を行うことによって, 環境教育として重要であり, 次期学習指導要領において要請されている自ら問題を発見する力 や推論する【思考】力を育てることができる可能性が示され, 学 習効果が得られるためには, 複数地点の学習を計画要素の中に入 れる必要がある」としたが, 本研究においても, 複数地点を学習 場所に入れることによって, 巟童の【思考】を育てる可能性があ ると推察された。また，「自分との関わり」を考えさせる指導が【思 考】を育てることが示唆された。

\section{（2）個別の児童の思考過程}

学習到達度によって，学級全体の児童 (20人) を個別にタイプ 分けをすると, 次の 3 つタイプに分類された。

1）【関心】・【理解】から【思考】に至るタイプ (8人)

2）【関心】から【理解】に至るが，【思考】に至らないタイ プ (10人)

3）【関心】は伸びるが, 【理解】や【思考】に至らないタイ プ (2人)

第 2 次から第 4 次までの「水生動物を使った環境学習」におい て, 児童 20 人のうち, 18 人が理解, 8 人が思考に至ったことから, このプログラムが【理解】を育てる有効性が示唆され，このプロ グラムによって，「深い学び」3) や【思考】が育つ可能性が示され た。小学校 4 年生という発達段階であっても, 「生物と空間」など の「自然の関連性理解」 ${ }^{16)}$ は，可能であることが示唆された。

【思考】に至った 8 人のうち，「祝戸はきれいが 6 種なのに，豊 浦は 2 種なので, 豊浦の水の方が污れている」（感想: 39）など第 3 次で記述した児童が 2 人,「ふらりかえると, 今までの調査で田原 本の川の水が一番きたないことがわかりました。（感想 : 58) な ど, 第 3 次で「水質判定の比較」を記述した児童が 7 人見られた。

また，学習したことと現場の観察の中から「川底がやわらかい とカゲロウは住みにくいとしたら, サホコカゲロウはなぜ住める のだろう」（感想：59）など，「自ら見つけた新しい問題」を記述 した児童が 2 人見られた。

また，「ヒルやサカマキガイを少なくできるようにしようと思 いました」(感想 : 60）「川を污すようなことをしないようにみん なでしていくと，もっと飛鳥川がきれいになり，生き物が住みや すくなると思います」（感想：63）という「自分との関わり」で記 述した児童が 2 人見られた。児童の中には, 教師からの勧め(Ø) もあり，学習したことを他の地域で適用したいといら意欲が生ま れ，「おばあちやんの家の前でとれた生き物は, 今日, 田原本でと れた生き物とやっぱり違いました」（感想 66）という行動と気づ きが生まれ，「夏休み，おばあちゃんの家の前で, おじいちゃんが どこらへんを探しているかを見て，私もやってみたい。（感想： 67）という二次的な「他地域への活動転化」への意欲が生まれた 児童が 1 人見られた。これら 3 人の児童は，嘉田が提唱寸る「自

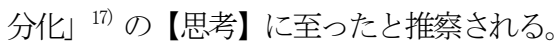

【関心】にとどまったのは，2 人の児童だった。そのうちの 1 人である児童 $\mathrm{A}$ は, 第 1 次で「泳いで夕たい, 第4 次で「石をわ たると意外とうれしかった」（感想：64）という記述がみられた。 遊ぶ活動に関心が向いていることから, 野外における学習におい

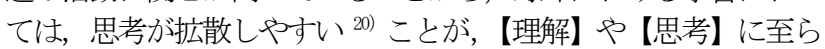
ない一つ要因ではないかと推察された。もう 1 人の児童Bの学 習対象は生物の領域への関心が中心となり，他の領域への関心が 少ない傾向にあった。それが「自然の関係性」の【理解】に達し なかった要因の一つ推察された。これらは, 今後の学習プログ ラムを作成する上での課題として示された。

\section{4. まとめ}

大和川水系飛鳥川の 3 地点で小学校 4 年の同一児童を対象に 4 回にわたる「水生動物を使った川の環境学習」を行った。そこ 


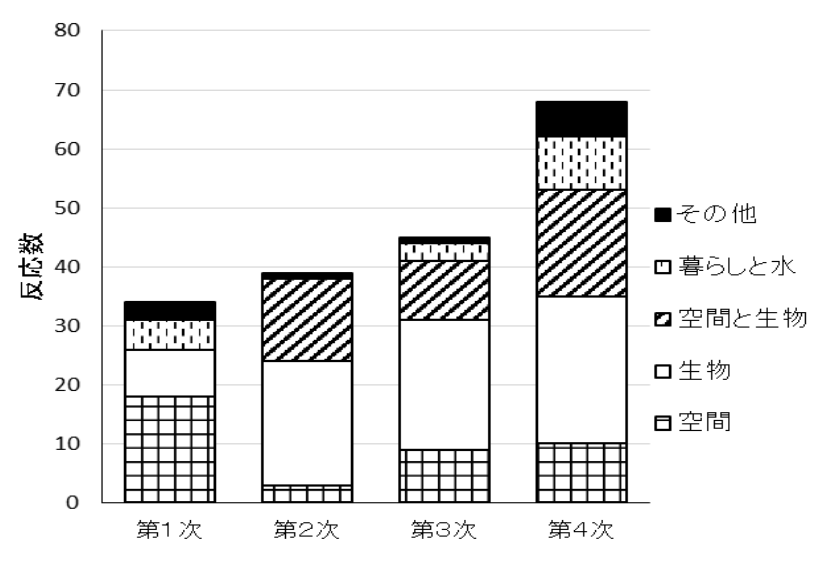

図-2 学級全体の対象の推移過程

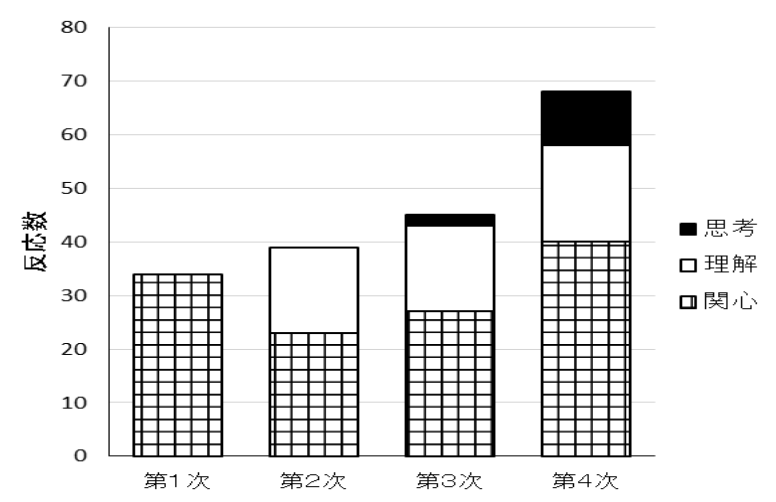

図-3＼cjkstart学級全体の反応レベルの推移過程

で得られた定量的な思考分析を基に，学級全体および個別の思考 過程がどのように推移したのかを分析し，上記の学習プログラム が児童の思考過程にどのような影響を与えたかを分析し，以下の 知見を得た。

川を外から観察するより，実際に川に入ることによって，川の 生物への【関心】が広がり，「生物と空間の関係性」への【理解】 が生まれ，複数地点を学習場所に選ぶ場合，同じ水系で水質など の環境の違いがより大きいほうが，监童の【思考】を育てる可能 性があることが示唆された。

学習到達度によって, 学級全体の学習過程を分析すると, 本研 究で対象にされた学習プログラムによって【関心】から【理解】,

【理解】から【思考】に反応レベルが進んでいることが分かった。 また, 巟童の個別の学習過程を分析寸ると, 児童全体 20 人のうち, 18 名が【理解】に至っており，この学習プログラムによる一定の 学習効果が得られていることが分かった。また，8名が【思考】 に達しており，3 名が学習内容を「自分化」していると推察され た。しかし，2 人の児童は，【関心】から【理解】や【思考】に達 しておらず，「思考の拡散」や「関心領域の狭さ」などがその要因 の一つではないかと推察された。

「水生動物を使った川の環境学習」を「環境条件や水質の条件 が異なる」複数地点で実施し，「自分との関わり」について考え させる指導を行うことによって, 環境教育として重要であり, 次 期学習指導要領において要請されている「自ら問題を発見する力」 や「推論」などの【思考】を育てることが示唆された。

なお，他教科の影響や学習の反復による学習への慣れが児童の 記述に影響を与えたことを否定できないため，それらの解析が必 要であること, および定量的な分析を行うためのサンプル数の確
保が，今後の課題として残された。

謝辞 : 本研究をまとめるにあたり，長年にわたって河川調査を 御指導いただいた奈良産業大学故御勢久右衛門名誉教授，資料整 理に御助力いただいた橿原中学校辻野寿彦氏，学習に協力いただ いた児童や教員に感謝申し上げます。

\section{補注及び引用文献}

1）国立教育政策研究所教育課程研究センター（2007）：環境教育指導資料: 国立教育政策研究所教育課程研究センター, 109pp

2）水山光春編（2013）：よくわかる環境教育 : ミネルヴァ書房，42-43

3) 文部科学省 (2017)：小学校新学習指導要領 : 文部科学省, 170pp

4）環境庁水質保全局（1986）：水生生物による水質の調査法 : 環境庁水質 保全局, 27pp

5）環境省水環境部・国土交通省河川局編（2000）：川の生き物を調べよう 一水生生物による水質判定一: 環境省水環境部・国土交通省河川 局, 36pp

6) 柴田真介 (2016) : 地域の自然との関わりを深める生活科学習: 椙山学 園大学教育学部紀要 $9,135-146$

7）荻原正直・川上昭吾（2003）：愛知県河川の実態調査を基にした水生生 物調查の改善と小学校における実践的研究:愛知教育大学教育実践セン 夕一紀要 (6), 145-150

8）河川環境財団（2006）: 水辺から学ぼう 小中学校活動事例集 : 河川環境 財団, 49pp

9）佐竹俊之・上甫木昭春（2004）：世代別に捉えた子どもの水辺遊びの変 容に関する研究一奈良県生駒郡平群町におけるケーススタディー:環境 情報科学論文集 18，107-112

10）山田一裕・須藤隆 - (1998) : 水辺環境の状況が览童の環境意識に与え る影響 : 環境教育 7 (2) , 50-59

11）白井信雄 (1996) : 環境配慮意識の形成要因としての自然とふれあう遊 びに関する研究 : 環境情報科学論文集 10，105-110

12）伊藤嘉奈子・天野邦彦・冨田陽子・原野崇・岸田弘之・宮尾博一・吉 野英夫・並木和弘 (2011) : 学校での河川学習の効果と河川教育プログ ラムに関寸る研究 : 河川技術論文集 17，389-394

13）本庄眞・浦出俊和・上甫木昭春 (2017) : 水生動物を用いた川の環境学 習における览童の反応レベルに関する研究 : ランドスケープ研究（オ ンライン論文集) $10,142-148$

14）文部科学省の小学校学習指導要領（平成 22 年 5 月 11 日文部科学省初 等中等教育局長通知）は，「学習評価における観点」を（i ）「関心・ 意欲・態度」,（ii）「技能」及び「知識・理解」,（iii）「思考・判断・ 表現」の 3 段階で示している。

15）押田佳子・山田昌枝・上甫木昭春 (2005) : 自然環境教育を通じた児童 が抱く理想の浜辺風景の変化に関する研究:ランドスケープ研究 68 (5), $457-462$

16) 宮本直樹 (2015) : 河川の水環境学習実践における「自然の関連性理解」 に関寸る考察 : 環境教育 24（3）, 123-129

17）嘉田は，「主体にとって環境の意味は，環境に働きかけを行うことで， 新たな意味が生夕出され，その意味が新たな認識を生夕出していく」 18) として, 琵琶湖博物館構想の中で, 来場者が琵琶湖と人（自分）の 関わりを作る場となるために，「自分化」をテーマとした博物館構想を 提唱した ${ }^{19)}$ 。本研究においては，「自分化」を『対象を「自分ごと」 として認識・思考して行動すること』と定義する。

18）嘉田由紀子（1997）: 生活世界の環境学, (社) 農山漁文化協会, 62-65

19）嘉田由紀子・古谷佳信（2008）：生活環境主義で行こう！：岩波書店, 96-97

20) 本庄眞 (1992) : 自然に親しみ, 科学的な見方や考え方を育てる指導法 の研究一地域素材の教材化を通して一: 奈良県教育センタ一研究集録, $1-5$ 